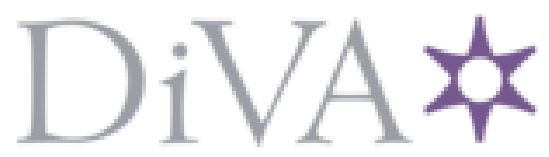

http://www.diva-portal.org

This is the published version of a paper published in Revista iberoamericana de estudios de desarrollo / Iberoamerican Journal of Development Studies.

Citation for the original published paper (version of record):

Lalander, R. (2014)

Rights of nature and the indigenous peoples in Bolivia and Ecuador: A Straitjacket for Progressive Development Politics?.

Revista iberoamericana de estudios de desarrollo / Iberoamerican Journal of Development Studies, 3(2): 148-173

Access to the published version may require subscription.

N.B. When citing this work, cite the original published paper.

Permanent link to this version:

http://urn.kb.se/resolve?urn=urn:nbn:se:su:diva-108843 

Development Politics?

\section{Derechos de la naturaleza y los pueblos indígenas en Bolivia y Ecuador: ¿Una camisa de fuerza para las políticas progresistas de desarrollo?}

\section{ResumenAbstract}

1. Introduction

2. Environmental Pragmatism

3. Sumak Kawsay and the Good Way of Living

4. Political Setting

5. Rights of Nature and the Indigenous Peoples: Constitutional Pragmatism?

6. TIPNIS and Yasuní

7. The Rights of Nature as a Straitjacket for Progressive Development Politics?

8. Conclusions

Acknowledgment

Bibliography 


\title{
Rights of Nature and the Indigenous Peoples in Bolivia and Ecuador: A Straitjacket for Progressive Development Politics?
}

Rickard LALANDER

Stockholm University (Sweden) Department of Political Science lalander@yahoo.com

\section{Derechos de la naturaleza y los pueblos indígenas en Bolivia y Ecuador: ¿Una camisa de fuerza para las políticas progresistas de desarrollo?}

\begin{abstract}
Is it possible to justify resource extractivism to provide progressive welfare politics and still respect the constitutional rights of nature? The Indigenous concept of Sumak Kawsay on human beings living in harmony with each other and the environment is the fundamental framing of the new constitutions of Ecuador and Bolivia. These constitutional reforms embrace strengthened proper rights of nature and similarly of ethnic rights. However, the same constitutions grant the State the right to exploit and commercialize natural resources and extractivism has increased. This study revises the tensions between welfare politics, extractivism and the rights of nature and the Indigenous peoples in the new constitutional settings of Bolivia and, particularly, Ecuador. The article argues that Sumak Kawsay challenges dominating understandings of the concepts of welfare, common good and development, and likewise that a pragmatic approach is applied by national governments towards the constitutional rights of nature amidst other human values.
\end{abstract}

Keywords: Bolivia, Ecuador, development politics, environmentalism, rights of nature and the indigenous peoples, Sumak Kawsay.

\begin{abstract}
Resumen
¿Sería posible justificar la extracción de recursos naturales para la provisión de políticas progresistas de bienestar y todavía respetar los derechos constitucionales de la naturaleza? La conceptualización indígena del Sumak Kawsay sobre los seres humanos en armonía entre sí y con el medio ambiente es el marco fundamental de las nuevas constituciones de Ecuador y Bolivia. Estas reformas constitucionales incluyen un fortalecimiento de los derechos propios de la naturaleza e igualmente de los derechos de los pueblos étnicamente definidos. No obstante, las mismas constituciones también otorgan al Estado el derecho de explotar y comercializar los recursos naturales y el extractivismo ha acelerado luego de la aprobación de estas constituciones radicales. Este artículo examina las tensiones entre políticas de bienestar social, extractivismo y los derechos de la naturaleza y los pueblos indígenas en los nuevos contextos constitucionales de Bolivia y, especialmente, Ecuador. Se argumenta, por un lado, que la filosofía de Sumak Kawsay desafía a las comprensiones dominantes sobre los conceptos de bienestar, bien común y desarrollo, y, por otro lado, que los gobiernos nacionales de los dos países han practicado una aproximación pragmática hacia los derechos constitucionales de la naturaleza en medio de otros valores humanos.
\end{abstract}

Palabras clave: Bolivia, Ecuador, ambientalismo, derechos de la naturaleza y los pueblos indígenas, desarrollo, Sumak Kawsay.

* Rickard Lalander is Adjunct Professor and PhD in Latin American studies, University of Helsinki. Currently he works as researcher at the Department of Political Science, Stockholm University. He has published broadly on democracy and social movements in the Andean countries and is author of the books Suicide of the Elephants? Venezuelan Decentralization between Partyarchy and Chavismo (2004), Retorno de los Runakuna. Cotacachi y Otavalo (2010), editor and co-author of Venezuelan Politics and Society in Times of Chavismo (2006). 


\section{Introduction}

We women and men, the sovereign people of Ecuador... hereby decide to build a new form of public coexistence, in diversity and in harmony with nature, to achieve the good way of living, the Sumak Kawsay (Preamble, Constitution of Ecuador 2008).

The way set forth by Socialism in the $21^{\text {st }}$ Century ought to better incorporate the way of life and the experience of the Indigenous peoples of the world who fundamentally defend the Mother Earth. Sisters and brothers, here are two paths. Either we follow the path of capitalism and death, or we advance down the Indigenous path in harmony with nature and life - everything to save humanity (Morales Ayma 2011:36). ${ }^{1}$

On a global level, the Bolivian and Ecuadorian governments of Evo Morales and Rafael Correa from 2006-2007 onwards are viewed as the probably most radical defenders of the rights of the environment/Mother Nature and as an option to the climate crisis and world capitalism, as expressed in several international summits, i.e., in Copenhagen in 2010. As uttered by Bolivian President Morales on the Day of Mother Earth (April 22, 2009) in the UN General Assembly: «The Earth does not belong to us, we belong to the Earth:» (Morales Ayma 2011: 49). Bolivia and Ecuador have among the richest biodiversity systems of the world, which are being threatened by the pollution and deforestation caused by industrial extraction of resources.

The new constitutions of Bolivia (2009) and Ecuador (2008) are the hitherto most radical constitutions of the world, both in the field of recognizing Indigenous grievances, such as legal pluralism, territorial autonomy and collective rights, and declaring the state to be intercultural and plurinational, ${ }^{2}$ and similarly the Rights of Nature, i.e., the constitutional protection of the environment/Mother Nature/Pachamama. With the recognition of proper rights of nature, the Bolivian and Ecuadorian cases similarly express a transition from an anthropocentric view on natural resources to a more bio-centric one (e.g., Gudynas 2011; Ramírez Gallegos 2012).

However, in practice powerful economic and political interests clash with Indigenous and environmental rights, and in the context of nationalization of vital industries - mainly hydrocarbons, agro-business (Bolivia) and mining - the Bolivian Constitution declares the industrialization and commercialization of natural resources to be key priority of the State, albeit taking into consideration rights of nature and Indigenous peoples and provided that revenues should be directed at the common good (art. 355). This is a central policy also of the Ecuadorian government, to a large extent backed up by the 2008 Constitution (e.g., in articles 275, $276,277,313,314,317$ and 395-399), subsequent legislation and the National Development Plan, as will be briefly discussed in due course.

The governments of Morales and Correa in Bolivia and Ecuador respectively have carried out ambitious social welfare reforms; poverty re- 
duction, health, education, improved infrastructure etc., leaning greatly on the export incomes of extractive industries. Bolivia and Ecuador are - together with Colombia and Paraguay - the South American countries with highest figures regarding poverty (CEPAL 2013: 19), ${ }^{3}$ and both countries depend highly on the export incomes derived from natural resources (Acosta 2009; Wanderley 2011; Arsel \& Ávila Ángel 2012; Dávalos 2013; Morales Ayma 2014 a). The development in terms of welfare policies rests on the State control and incomes of the key industrial production. Consequently, in the context of development and resource management, the strategic interests of the nation may conflict with the rights of nature and the Indigenous peoples.

Extractive activities have indeed increased in Bolivia and Ecuador during the period, as elsewhere in South American countries with Leftoriented governments. Several authors, such as social ecologist Eduardo Gudynas (2009b) and economist Pablo Dávalos (2013) refer to these changes as progressive neo-extractivism, characterized by a stronger role and presence of the state in extractive industries. The progressive trait and legitimation of this extractivist model is the usage of the revenues in state social programs, mainly education and health. So, even though extractive projects may threaten territorial rights, at the same time the social reforms generally benefit the Indigenous peoples and other marginalized groups.

This essay deals with the tensions and contradictions between ethnoenvironmental concerns and development politics in Bolivia and Ecuador. In both countries the Indigenous principle of Sumak Kawsay (vivir bien/ buen vivir, right livelihood) as well as the rights of the Indigenous peoples to prior consultation (and implicitly to free, prior and informed consent when new extractive projects are planned) are constitutionally established. At first sight, it could appear as if the new constitutions would undoubtedly benefit the Indigenous and ecologist actors, since they embrace many of those concerns voiced by the ethnically defined groups. However, these constitutions accentuate new tensions and contradictions, as manifest also in the constitutional rights of nature. ${ }^{4}$ Legal norms constrain and enable collective action and play an important role in shaping contentious politics. Further, legal struggles in Latin America are among the most frequent contentious repertoires of Indigenous groups, particularly in the recent neo-constitutional contexts of Bolivia and Ecuador.

The aim of the study is to identify and problematize the nature and implications of the constitutional contradictions and tensions between progressive welfare politics based on extractivism and constitutionally sacred rights of nature and the Indigenous peoples in Bolivia and, particularly, Ecuador. Is it possible to justify resource extraction in the name of the common good and still respect the constitutional rights of nature? Is the Sumak Kawsay model at all imaginable without «development» (economic growth) or is development a pre-condition in the path en route for the Good Way of Living with social wellbeing for all in these nations still plagued by poverty?
3 Certainly, statistics on poverty and indigence may be considered controversial and there are different possibilities to measure these issues. The above comment refers to the figures presented by CEPAL regarding the year 2011. It should be noted that Mexico, Central America and the Caribbean are excluded from the context presented here.

4 Of course, one could also argue that the fundamental contradictions go beyond the mere constitutions, i.e. in terms of discrepancies and gaps between the constitutions and implementation of politics. Although, I argue, also practical politics leaning on a particular constitutional article that goes against the objective of another central article - or even the model of society established in the Constitution (Sumak Kawsay) - are rooted in the original constitutional contradiction in question. Other (oppositional activist) scholars have focused on the alleged gaps and or inconsistencies between constitutional principles and politics in Ecuador and Bolivia, particularly concerning extractivism (see e.g. Acosta et al. 2013 and Prada Alcoreza 2014) 
The article argues that Sumak Kawsay challenges the hitherto dominating understandings of the concepts of welfare, common good and development. Furthermore, it maintains that in practice a more pragmatic approach is applied by national governments towards environmental rights among other human values. In the problematization of the contentious scenarios emerging in the clashes between constitutional rights and extractive policies, it is valuable to address the research questions through an analysis of the discourses pronounced by the key actors involved, and similarly in the formulations in written documents. The reasoning on behalf of the national government as regards extractive activities and the constitutional rights of nature merits particular attention. This exploration will lean on theoretical debates on the rights of nature in terms of tensions between ecocentrism and environmental pragmatism.

After the contextualization presented above, the disposition of the article is as follows. First, a philosophical discussion is offered around different ethical standings towards nature, particularly in terms of ecocentrism and environmental pragmatism. Second, the Sumak Kawsay concept is concisely presented, followed by a brief section on the political setting in Bolivia and Ecuador. Thereafter, a few essential articles of the two constitutions are examined, emphasizing the central contradiction of the study. Next, two concrete conflicts around the theme are presented; first briefly the TIPNIS highway project in Bolivia, and thereafter more in depth the Yasuní-ITT initiative in Ecuador. Before rounding off with a few pertinent conclusions and final remarks, the article discusses analytically the constitutional challenge and examines whether the rights of nature and the Indigenous peoples in reality have evolved into an obstacle for progressive development and welfare politics.

\section{Environmental Pragmatism}

Since this study deals with conflictive situations emerging in the clashes between constitutional rights, welfare policies and extractive projects, it is worthwhile to briefly examine the philosophical and ethical thoughts behind environmental discourses. Political scientist Robyn Eckersley (2002) theorizes on the tensions between ecocentric theory and environmental pragmatism amidst deliberative democracy. Whereas the ecocentric approach views nature as «sacred" and promotes the idea of zero extractivism, the more pragmatic position accuses ecocentrism to be too rigid, inflexible and indifferent regarding diverse moral and cultural circumstances.

The pragmatist approach towards the environment is anthropocentric, since human beings are the only ones that can discuss on values, simply because the human perspective is the only one we can really understand. At the same time, environmental philosopher Kelly A. Parker 
admits that we can feel or perceive the expressions of other species, e.g. trees or animals. However, that does not mean that we can «speak in their voices". The best thing human beings could do in this sense is to be the spokesmen of the other non-human being (Parker 1996: 33).

The intellectual debate on anthropocentrism is indeed characterized by a high degree of normativity and tendentious positions, due to its focus on values, moral and respective viewpoints.

Anthropocentrism maintains that value is of or for human beings. Biocentrism maintains that all forms of life, as such, are valuable. Ecocentrism emphasizes the value of ecological systems as a whole, including natural processes, relationships and non-living parts of the environment. An aspect of this debate concerns whether value attaches to individual entities or whether value must be seen holistically (Parker 1996: 32).

Environmental pragmatists hold that they are more effective in practical solutions of environmental problems, more open-minded as for cultural diversity and moral pluralism, and likewise more democratic regarding its justification of environmental policy deliberation by concerned actors. Ecocentric advocates, on the other hand, may claim that the pragmatic defense of moral pluralism might lead to indecisive relativism (Eckersley 2002).

However, it is frequently difficult to draw an exact boundary between the two standpoints. The ecologist anxieties of environmental pragmatists may indeed be sincere, but in political contexts other values related to human needs, i.e. poverty reduction and provision of welfare might be more pressing in the shorter perspective for the political leadership.

As mentioned previously, the recognition of proper rights of nature in the Bolivian and Ecuadorian constitutions reflect a transition from an anthropocentric view on natural resources to a relatively more biocentric one, although it would not be correct to label the entire constitution biocentric or ecocentric, considering the inherent contradictions mentioned previously. In due course, I will argue that anthropocentric values (pragmatism) tend to dominate over the more ecocentric approaches in recent Bolivian and Ecuadorian developments.

\section{3 \\ Sumak Kawsay and the Good Way of Living \\ The Good Way of Living is planned, not improvised. The Good Way of Living is a form of life that permits happiness and the durability of cultural and environmental diversity; it's harmony, equality, fairness and solidarity. It is neither question of the pursuit for wealth, nor infinite eco- nomic growth (Fragment, new Ecuadorian Development Plan for the Good Way of Living; SENPLADES 2013: 13).}


5 Buen-vivir (Spanish) and Sumak Kawsay (Kichwa) are the conceptual labels used in Ecuador, whereas in Bolivia the corresponding concepts are Vivir bien (Spanish) and Suma Qamaña (Aymara). The Ecuadorian conceptual terminology is more frequently used at international level and generally in this text I will refer to these principles in their Ecuadorian names.

6 These two, Acosta and Gudynas, are leading (nonIndigenous) intellectual authorities in the thematic field of Sumak Kawsay and the Good Way of Living. In fact, Acosta was previously Ecuadorian Minster for Energy and Mining and presided the Constitutional Assembly that drafted the Constitution of 2008. Gudynas was also involved in the constitutional reform in Ecuador and assisted Acosta in the Assembly.

7 Due to the limited extension of the present article, a more detailed problematization of the differing viewpoints on Sumak Kawsay on behalf of the Indigenous actors will not be offered here. One of the most ambitious books so far on the Indigenous understandings of Sumak Kawsay in Ecuador was recently presented in a collaboration project between the universities of Cuenca, Ecuador, and Huelva, Spain. The book includes analytical interpretations written by a large number of intellectual authorities of the Ecuadorian Indigenous movement (Hidalgo Capitán, Guillén García \& Deleg Guazha 2014). This recommendable book is also available on-line: http://www. uhu.es/cim/documents/ agenda/libro_sumak.pdf>.
The backbone of the new constitutions of Bolivia and Ecuador is the ethical and philosophical conception of Buen-vivir/Sumak Kawsay. ${ }^{5}$ Sumak Kawsay could crudely be translated to right livelihood or living well. It is important to emphasize that the idea is to live «well» and not «better», i.e. not striving for material improvement, to live better and better on an individual level, or better than the neighbors and so forth. On a national and international level the challenge would be to end the competition on the global capitalist market. In that sense, Sumak Kawsay emerges as an alternative to the notion of development, questioning its mere essence. Authors such as economist Alberto Acosta (2009; 2012) and Eduardo Gudynas (2009 a; 2011) actually speak of Sumak Kawsay and the groundbreaking constitution of Ecuador in terms of a post-development and dissolution of the notion of progress. ${ }^{6}$

Philosophically, the promoters of Sumak Kawsay suggest that development/progress as most people understand it is unnecessary. Individual as well as national economic «progress" and «wellbeing" in terms of material belongings and capital accumulation and so forth according to traditional notions of development should be compared with a life in harmony with the environment and other human beings, without the pressure of global capitalism on the nations and of consumptionism on individuals and collectives.

It merits emphasizing that among the Bolivian and Ecuadorian Indigenous peoples the aspects of territoriality and harmonic relationship with the environment are central as concern ethno-cultural rights. Identitarian elements of ethnicity, cultural practices, territoriality and nature-environment are intimately and complexly intertwined (e.g., Albro 2010; Acosta 2012). As for the Indigenous roots of the concept, ${ }^{7}$ one spokesperson of the Ecuadorian Indigenous movement, Amazonian Kichwa leader Mónica Chuji Gualinga, argues the following regarding the Indigenous interpretations of Sumak Kawsay, including its relationship with development:

In the Indigenous world, Sumak Kawsay (harmonious life or Buen Vivir) signifies having healthy and fertile land and territory. It implies cultivating only the necessary and to think about the diversity of crops. Further, to preserve, cherish and maintain the rivers, forests, the air, the mountains, etc., clean. It also means disposing a territory that is managed collectively; education based on our proper values; and a constant communication. It also signifies a commitment to an ethical code and the recognition and respect of the rights of others [...]

Sumak Kawsay [...] advocates that nature should no longer be viewed as a factor of production or as a productive force, but instead as an inherent part of the social being [...] Sumak Kawsay questions the theories of development, which proposed the existence of «developed», «under-developed» (or "developing») countries, and they even recommended receipts to overcome this state of underdevelopment. The core of the receipt was to extend the exploitation of nature, decrease rights and to commercialize the labor force (Chuji Gualinga 2014: 231-233).

The concept of development is complicated in the recent political scenarios of Bolivia and Ecuador. In the Ecuadorian case, for instance, 
the State does not reject the concept as such. Rather, a problematization and more critical (and complex) usage of the concept are applied. Article 275 of the 2008 Constitution states the following regarding the development structure in relation to Sumak Kawsay and the rights of nature and the Indigenous peoples:

The development structure is the organized, sustainable and dynamic group of economic, political, socio-cultural and environmental systems which underpin the achievement of the good way of living (Sumak Kawsay). The State shall plan the development of the country to assure the exercise of rights, the achievement of the objectives of the development structure and the principles enshrined in the Constitution. Planning shall aspire to social and territorial equity, promote cooperation, and be participatory, decentralized, deconcentrated and transparent. The good way of living shall require persons, communities, peoples and nationalities to effectively exercise their rights and fulfill their responsibilities within the framework of interculturalism, respect for their diversity, and harmonious coexistence with nature.

The principles of the State transformation are presented precisely in the National Development Plan for Good Living (Plan Nacional de Desarrollo para el Buen Vivir) and consequently the doctrine of Sumak Kawsay/Buen-vivir is incorporated in the public strategies of «progress». In the Ecuadorian National Development Plan for Good Living the rights of nature and its protection are established, although in a more realistic than naïve or exaggeratedly romantic/utopic manner. For instance, regarding the harmonic relationship with nature it declares that:

Ethical responsibility with the current and future generations and with the rest of species is a critical foundation to prefigure human development. It acknowledges economy's dependence on nature; it admits that economy is part of a broader structure - the ecosystem - which supports life as a resource-supplier and waste drain [...] It is not about keeping our natural heritage unharmed - given the use of energy and materials by different societies and given the ecosystems' assimilation capacity, this is impossible-. It is about protecting at the adequate levels (SENPLADES 2009: 21).

\section{4 \\ Political Setting}

The notion $21^{\text {st }}$ Century Socialism appeared gradually already in the 1990s as a reflection of the discontentment with neo-liberalism in Latin America. The novelty of the concept is expressed - not only in terms of differing historical contexts - but also in its rejection of the Soviet socialist model, considering its dictatorial traits and economic malfunction. Broadly speaking, the $21^{\text {st }}$ Century Socialism endorses increased state regulation and authority within a democratic structure and strives for a more efficient distribution of resources. Traditionally excluded actors are motivated to take a more active part in politics and economic production (e.g., Kennemore and Weeks 2011). 
In Bolivia and Ecuador, the Leftist political turn in governments is the results of decades of (Indigenous) social movements' struggles against neoliberal politics. In 2005, Evo Morales Ayma was elected President of Bolivia, the first Indigenous President of Latin America, representing the political party MAS (Movimiento Al Socialismo) and backed up by a conglomerate of social movements. The election of Evo Morales can be viewed as the culmination of a protest movement against exclusionary political and economic structures and also as recognition of (mainly Indigenous) citizens and collectives that previously were marginalized.

The Indigenous peoples had struggled for decades for deepened autonomy and dignity as peoples, since 1989 further triggered by the ILO Convention 169. In 1990, the lowland Indigenous confederation CIDOB (Confederación de Pueblos Indígenas de Bolivia) organized a great march for Territory and Dignity from Trinidad in the lowlands to La Paz. Also highland Indigenous organizations intensified pressure during the period and the 1990s saw several legal recognitions of the ethnically defined grievances, such as the Law of Popular Participation of 1994 and the approval of Indigenous territorial units/TCO (Territorio Comunitario de Origen). In the awakening of the new millennium, the emerging movement around Evo Morales was in the epicenter of resource conflicts, most importantly during the so-called "water war» in 2000 and the "gas war» in 2003.

In Ecuador, in 2006 economist and radical catholic Rafael Correa Delgado triumphed in the presidential elections on the platform of the PAIS Alliance (Alianza PAIS/Patria Altiva I Soberana/Proud and Sovereign Fatherland). Once elected, plans to restructure the political system via a constitutional reform were initiated (as was also the case in Bolivia). The main banner of the electoral campaign of Correa in Ecuador was ${ }_{i}$ Constituyente Ya! («Constitutional revision right now!») and the agenda mainly included issues/demands from the Indigenous movement. Since the 1980s, the Indigenous movement, spearheaded by the CONAIE confederation (Confederación de Nacionalidades Indígenas del Ecuador) has occupied an important space in the Ecuadorian political society.

There is a direct link between the advancements of the political project of Rafael Correa and the Indigenous movement. In 1995, CONAIE together with other social movements established a political party (or political movement as they prefer): Pachakutik, to be able to compete on the electoral arenas and there through being able to achieve representational spaces in State institutions. Pachakutik has since then been successful in elections, particularly at sub-national levels.

In the national elections of 2002, the Indigenous movement allied itself with lieutenant colonel and former coup leader Lucio Gutiérrez as presidential candidate. Gutiérrez triumphed and the Indigenous movement as the key ally thus reached inclusion in the national government, 
including two ministerial posts for CONAIE-Pachakutik representatives. The alliance lasted only six months, though, and the Indigenous movement withdrew from government to re-establish itself in political opposition. Since this short-lived Gutiérrez alliance, the Indigenous movement has experienced a crisis, expressed most of all in deepening discontent on the part of the grassroots with the national leadership of CONAIE and Pachakutik. Nonetheless, signs of a crisis had appeared already before the Gutiérrez alliance, related among other things to the participation of Indigenous leaders in the previous governments, for example during the previous presidencies of Abdalá Bucarám (1996-1997) and Jamil Mahuad (1998-2000).

In recent times, Indigenous oppositional actors often claim that Correa has divided the CONAIE-Pachakutik and coopted many of their leaders and grassroots activists. Indeed many former leaders of the Indigenous movement today hold important positions on different political-territorial levels within the Correa government. Particularly since 2009, the relationship between the Correa government and the Indigenous movement has been hostile (antagonistic), despite sharing many principal objectives. The principal grievances during recent protest activities organized by the Indigenous organizations have focused precisely on the respect of the rights of nature (water, anti-mining, etc.) and the dignity of the Indigenous population (e.g., Lalander and Ospina Peralta 2012).

Before the Correa presidency, large scale mining was not a strategic economic activity for the Ecuadorian development model. Small-scale mining including artisan mining has developed in Southern Ecuador. In the 1990s, the mining sector experienced attraction of foreign capital investments and anti-mining protests against transnational companies increased gradually. A central protest organization has been Acción Ecológica. From 2002 onwards, protest activities have augmented, at times leading to social clashes and violence (Latorre Tomás 2012). On several occasions, Indigenous and environmentalist activists have been imprisoned for taking part in protest activities, both in Bolivia and Ecuador, labeled by the government as saboteurs. The oppositional Indigenous actors refer to this issue as a criminalization of social mobilization (e.g., Bebbington and Humphreys Bebbington 2010: 11; Lalander and Ospina Peralta 2012).

In Bolivia, the State-Indigenous relationship presents a similar pattern as for the political and organizational division of the Indigenous peoples. However, Bolivia does not have one Indigenous confederation of national coverage that could be compared with the Ecuadorian CONAIE, rather the Indigenous representative scenario has been divided, although the key organizations unified behind Morales in 2005 and during the first years of his administration. Among the principal ethnically defined organizations that initially backed up Evo Morales for the presidency, two of these -lowland Indigenous confederation CIDOB and the highland Aymara and Quechua Council CONAMAQ (Consejo Nacional de Ayllus y 
Markas del Qullasuyu) are since several years in outspoken opposition to the government, particularly concerning extractivist policies. ${ }^{8}$ The organizations that still support the government are the Bolivian Workers Central/COB (Central Obrera Boliviana), ${ }^{9}$ the peasant union CSUTCB (Confederación Sindical Única de Trabajadores Campesinos de Bolivia), the Bartolina Sisa National Confederation of Peasant, Indigenous, and Native Women of Bolivia/CNMCIOB-BS (Confederación Nacional de Mujeres Campesinas Indígenas Originarias de Bolivia Bartolina Sisa), and the most important one (in numbers of members): the Unionist Confederation of Intercultural Communities of Bolivia/CSCIB (Confederación Sindical de Comunidades Interculturales de Bolivia). The backbone of this last organization - the CSCIB - is the coca-growing migrants, originally from the highlands but in recent time established in broader areas in the Bolivian lowlands.

\section{5 \\ Rights of Nature and the Indigenous Peoples: Constitutional Pragmatism?}

Now then, in order to have a better idea of the legal scenery, in this section a few of the central articles in the constitutions regarding the contradiction of the study will be emphasized. As concerns the proper rights of nature, the Ecuadorian Constitution of 2008 includes an entire chapter. Article 71 declares the following:

Nature, or Pacha Mama, where life is reproduced and occurs, has the right to integral respect for its existence and for the maintenance and regeneration of its life cycles, structure, functions and evolutionary processes.

All persons, communities, peoples and nations can call upon public authorities to enforce the rights of nature. To enforce and interpret these rights, the principles set forth in the Constitution shall be observed, as appropriate. The State shall give incentives to natural persons and legal entities and to communities to protect nature and to promote respect for all the elements comprising an ecosystem. faction supporting the Morales government and the other in opposition. Already by late 2010, the CIDOB divided and presently there are two CIDOBs, one pro-government and the other oppositional.

9 The relationship between the Morales government and $\mathrm{COB}$ has experienced tensions in recent years. In early 2012 COB withdrew its support to Morales, but later in November 2013 the workers'central decided to return to the alliance.

It is illustrative that Nature is used synonymously with Pachamama, the Indigenous concept of Mother Earth, not only in this article. As seen in the second sentence of the article, since nature (including wildlife) cannot speak directly for its own sake and rights, any citizen or collective may state demands representing nature. Further, in article 72 , the rights of nature to restoration in case of damages are declared. Subsequently, article 73 states the preventive and restrictive measures that the State should apply regarding activities that might lead to the extinction of species, devastation of ecosystems or permanent change of natural cycles are articulated. Both articles 72 and 73 are thus clearly ecocentric and biocentric, as also the first part of article 71 . Article 74 is more anthropo- 
centric and declares the rights of individuals and collectives to benefit from nature and the environment in order to Live Well.

By merely analyzing the constitutions of the two countries, there is a more advanced (constitutional) protection of the rights of nature in Ecuador. However, partly recompensing for this difference, on October $15^{\text {th }}$, 2010, the government of Evo Morales in Bolivia launched the Law of Mother Earth. The law endorses harmony, peace and the abolition of all biological, chemical and nuclear weapons, and encompasses, among others, the following rights:

- maintenance of the integrity of life and natural processes,

- the non-permission of modified or genetically altered cellular structure,

- continuation of vital life cycles and processes free from human alteration,

- pure water and clean air,

- balance and equilibrium,

- to be free of toxic and radioactive pollution,

- to not be affected by mega-infrastructure and development projects that disturb the balance of ecosystems and local resident communities.

In September 2012 the law was upgraded by the National Legislative Assembly as the Framework Law of Mother Earth and Integral Development to Live Well/Ley Marco de la Madre Tierra y Desarrollo Integral para Vivir Bien (Estado Plurinacional de Bolivia 2012). The framework character of the law signifies that it is superior to other laws. For instance, the laws of mining, hydrocarbons, water etc. should correspond to the contents of the framework law. The second part of the law merits highlighting, namely the integral development which alludes to the objectives of the good way of living/vivir bien beyond the merely environmental concerns and the proper rights of nature. Even if the environmental concerns are central, the integral development component adds a more pragmatic dimension in considering human needs and rights as well. By early 2014 , the impact of the Framework Law of Mother Earth and Integral Development to Live Well cannot be clearly evaluated, since secondary legislation in concerned areas needs to be drafted in order to adapt these laws to the new legal framework.

Returning to the Ecuadorian Constitution of 2008, below the title of the rights of communities, peoples and nations, the first part of article 57 declares that:

Indigenous communes, communities, peoples and nations are recognized and guaranteed, in conformity with the Constitution and human rights agreements, conventions, declarations and other international instruments, the following collective rights: 1 . To freely uphold, develop and strengthen their identity, feeling of belonging, ancestral traditions and forms of social organization. 2. To not be the target of racism or any form of discrimination based on their origin or ethnic or cultural identity. 
Furthermore, the same article 57 specifies that:

The territories of the peoples living in voluntary isolation are an irreducible and intangible ancestral possession and all forms of extractive activities shall be forbidden there. The State shall adopt measures to guarantee their lives, enforce respect for self-determination and the will to remain in isolation and to ensure observance of their rights. The violation of these rights shall constitute a crime of ethnocide, which shall be classified as such by law [words in italics by author].

The remaining parts of the same article concern Indigenous territorial rights and similarly the right to free, prior, informed consultation in situations of planned resource extraction in their lands. It likewise declares that the local Indigenous population is guaranteed compensation for possible social, cultural and environmental damages caused by extractive activities and furthermore that they should be benefitted from the incomes derived from this industry. Nevertheless, the right to prior consultation of the affected population as regards resource exploitation has thus far not been clearly established as the norm in Ecuador. However, in both Bolivia and Ecuador, the right to prior consultation is recognized through the Hydrocarbon Laws, although so far not in the field of the mining industry.

In the Bolivian Constitution of 2009, the territorial rights of the Indigenous peoples are expressed in articles 394-395:

The State recognizes, protects and guarantees communitarian or collective property, which includes rural native Indigenous territory, native, intercultural communities and rural communities. Collective property is indivisible, may not be subject to prescription or attachment, is inalienable and irreversible, and it is not subject to agrarian property taxes. Communities can be owners, recognizing the complementary character of collective and individual rights, respecting the territorial unity in common.

The lands that are taken over shall be given to rural native Indigenous peoples, intercultural Indigenous communities, Afro-Bolivian and rural communities, which do not possess them or have insufficient lands, in accordance with state policy concerned with the ecological and geographic realities, as well as the population, social, cultural and economic necessities. The endowment shall be carried out according to the policies of sustainable rural development and the right of women to access, distribution and redistribution of land, without discrimination based on civil status or marital union.

However, as mentioned in the introductory contextualization, the same constitution likewise expresses the rights of the State to explore the natural resources of the soil, as pronounced in article 355, which also indicates the destination of the incomes derived from these activities:

I. The industrialization and sale of natural resources shall be a priority of the State.

II. The profits obtained from the exploitation and sale of the natural resources shall be distributed and reinvested to promote economic 
diversification in the different territorial levels of the State. The percentage of profits to be distributed shall be approved by the law.

III. The processes of industrialization shall be carried out with preference given to the place of origin of the production, and conditions shall be created which favor competitiveness in the internal and international market.

In Ecuador too, even if no defined article declares exactly the same as the first point presented above, the essence of the right to exploitation and commercialization of natural resources is indeed expressed in terms of strategic interests of the nation and as a fundamental resource for the carrying out of social welfare policies (e.g., in articles 275, 276, $277,313,314,317$ and 395-399), as mentioned in the introduction. For instance, in article 276, the complex nature of the development objectives are reflected:

1. To improve the quality of life and life expectancy, and enhance the capacities and potential of the population within the framework of the principles and rights provided for by the Constitution. 2. To build a fair, democratic, productive, mutually supportive and sustainable economic system based on the egalitarian distribution of the benefits of development and the means of production, and on the creation of decent, stable employment [...] 4. To restore and conserve nature and maintain a healthy and sustainable environment ensuring for persons and communities equitable, permanent and quality access to water, air and land, and to the benefits of ground resources and natural assets. 6 . To promote balanced, equitable land use planning, integrating and coordinating socio-cultural, administrative, economic and management activities and bolstering the unity of the State.

The article likewise emphasizes the rights of the ethnically defined peoples and the cultural heritage. Evidently, policies regarding labor/employment, economic production, social welfare, rights, democratic principles and environmental concerns are embedded in one and the same article. The following article (277) underlines the general responsibilities of the State in order to accomplish the Good Way of Living, undoubtedly leaning on visions of economic production and development in the traditional meaning, albeit respecting the constitutional rights of the peoples and Pachamama:

1. To guarantee the rights of people, communities and nature.

2. To direct, plan and regulate the development process.

3. To make and implement public policies, and to control and sanction any breach thereof.

4. To produce goods, to create and maintain infrastructure, and to provide public services.

5. To boost the development of economic activities through a legal system an,d political institutions that promote, foster and defend said activities in observance of the Constitution and the law.

6. To promote and bolster science and technology, the arts, ancestral wisdom and, in general, activities resulting from the creative initiative of communities, associations, cooperatives and the private sector. 


\section{TIPNIS and Yasuní}

The constitutional contradictions presented in the introduction of this study - the clashes between economic development politics and the rights of nature and the Indigenous peoples - have been in the center of recent contentious politics in Bolivia and Ecuador. As for recent social clashes, in March 2012, I observed how Ecuadorian Indigenous organizations marched for 15 days until reaching Quito in thousands, claiming respect for the Constitution on environmental and ethnic rights. The two most emblematic conflicts, however, concern the cases of TIPNIS highway project in Bolivia and the Yasuní-ITT initiative in Ecuador. These two are most suitable to illustrate the central argument of the article and merit a bit more detailed presentation, particularly the Yasuní case. These two manifestations are likewise good examples of modified repertoires of the social movements as regards networking and the usage of digital media in combination with more traditional modus operandi, such as the protest march in itself. New blogs and cyber-networks have been created, merging activists and politicians with academics. On Facebook there are several groups around the defense of TIPNIS and Yasuni respectively.

As regards the first case, TIPNIS, in October 2011 a huge number of Indigenous and other activists marched for 65 days from the Bolivian lowlands to the capital protesting against a highway construction project through a protected area and Indigenous territories (TIPNIS/Territorio Indígena y Parque Nacional Isiboro Secure). The 602 kilometers highway project would connect the lowland Beni department with highland Cochabamba. The protesters presented a list of 16 demands concerning respect for the territory as well as other social, economic and cultural concerns. After a few violent clashes between police forces and the marchers, President Morales agreed to all demands presented. However, after a few months the highway project was reinitiated, despite heavy resistance and international media and academic coverage (e.g., Fundación Tierra 2012; McNeish 2013).

However, the TIPNIS conflict suddenly ended in a rather strange way. During recent fieldwork in Bolivia in January 2014, I perceived how local academics and activists were surprised to say the least about some declarations quoted in the local mass media on January $4^{\text {th }}$ (e.g., Página Siete 2014) that vice-President Álvaro García Linera has expressed in June of 2013 at a conference in Argentina, i.e., half a year before, regarding the destiny of the TIPNIS highway. García Linera had admitted several mistakes on behalf of the government toward the highway construction and the communication with affected Indigenous groups. He emphasized that the highway will be necessary but that it had to be postponed 20,50 or 100 years and should be carefully carried through as regards protection of the environment (García Linera 
2013; Página Siete 2014). During personal conversations in La Paz in January and February 2014, even government officials confirmed that the highway was cancelled. Still, it remains to be seen whether this position on behalf of the government is preserved after the presidential elections of October 2014.

In Ecuador, the government of Rafael Correa has since 2007 developed an alternative to capitalist resource management in the Amazonian territory of Yasuní, home of several Indigenous groups and with the richest biodiversity of the world, but also a territory of unexploited oil richness. With the slogan of «Leaving the oil underground» Ecuador asked the international community for $50 \%$ of the incomes that would have been generated from oil exploitation, in order to protect the biodiversity and the Indigenous peoples of the area (some of which live in voluntary isolation), which adds to the image of Ecuador as the most progressive country in the world vis-à-vis the rights of the environment. For this purpose, the government together with the UNDP created the Yasuní-ITT ${ }^{10}$ trust fund to administer the donations (co-responsibility). The initial compromise of the Ecuadorian government was to leave approximately 850 million barrels of oil underground without time limits.

The initiative is a rejection of oil capitalism and dates back many years. In 1995 the Indigenous Confederation CONAIE demanded the suspension of oil drilling in the Yasuní national park, and later the proposal was developed among academics and different civil society groups of environmental concern, such as Oilwatch and Acción Ecológica. Although, it was implemented by the Correa government in 2007, that is, even before the popular approval of the new constitution in 2008. And, important to emphasize, the component of the international compensation within the initiative was invented by the Correa government.

The Yasuní Project early enjoyed worldwide praises, and academics and activists even began speaking of a "Yasunization» in other parts of the world. Yasuní-ITT became the symbol of another possible world and a rejection of extractive capitalism. As was also the case in Bolivia with the TIPNIS experience, Yasuní became a national banner of Ecuadorians all over the country, around the identification with the ecologist objectives of the project. «l am Yasuní» (Yo soy Yasuni) or «We are all Yasuní» (Todos somos Yasuni) are popular slogans in Ecuador (as also "Yo soy TIPNIS» and «Todos somos TIPNIS» in the Bolivian case).

The great majority of the Ecuadorian population supports the YasuníITT initiative according to popular surveys. The Yasuní-ITT initiative, together with the rights of nature in the Constitution is undoubtedly the most important and symbolical contribution of Ecuador on a global level. Was it too good to be true? Rumors already circulated in Ecuador and beyond that it was only a question of time before oil drilling would initiate in this part of the Amazon.
10 ITT refers to three untapped oil blocks known collectively as Ishpingo-Tambococha-Tiputini. It should be mentioned that the Yasuní-ITT initiative was launched in collaboration with the international community as a pilot project under the title of Net Avoided Emissions within the agenda of the Ad Hoc Working Group on Long-Term Cooperative Action under the United Nations Framework Convention on Climate Change/AWG-LCA (UNFCCC 2011). 
Finally, on August 15, 2013, President Rafael Correa officially declared the ending of the Yasuní-ITT initiative and thus gave green light for oil drilling in this natural park of the Amazon. He claimed it was his «toughest political decision ever»... «Deeply saddened, albeit with responsibility, I have signed the executive decree for the liquidation of the Yasuni-ITT trust fund and through it, end the initiative", Correa said in a televised discourse (Correa Delgado 2013) and the closure of Yasuní-ITT was similarly officially rooted via a Presidential decree.

One of the most distinguished scholars on Indigenous studies in Latin America is Bolivian-Catalan anthropologist and Jesuit priest Xavier Albó. When he heard of the closure of the Yasuní-ITT initiative he immediately wrote a short requiem, among others with the following statement:

The Yasuní-ITT initiative is the most radical and bold proposal I know of regarding the relationship between the respect of Mother Earth and development in national parks of high biological diversity and valuable natural resources in the subsoil (Albó 2013).

The arguments on behalf of the government were, above all that the international community failed them. Only $0.37 \%$ of estimated contributions had been achieved. And, incomes are needed for social reforms, to combat poverty, build schools and hospitals, etc., especially in the Amazon. Furthermore, Correa argued that over $99 \%$ of Yasuní will remain intact, and only $0,1 \%$ of the Yasuní territory directly affected by the oil drilling. He emphasized that the latest technology available will be used in order to minimize the environmental impact and possible consequences for affected Indigenous peoples. Additionally, Correa argued that the oppositional ecologist activists build their discourse around a false dilemma regarding the relationship between nature and extractivism. The reality is more complicated, "the world does not function like that» according to the President, and the «minimal environmental damage» caused by the planned oil drilling should be balanced with the possibilities to improve life conditions for the people living in the Amazon. An additional important argument, similarly valid beyond the Yasuní case, concerns the national control of the extractive industries. According to this logic there is a decisive difference between foreign/transnational versus natural extractive companies and national companies are expected to be more concerned with the environmental aspects and the rights of the local affected population (Correa Delgado 2013).

The Ecuadorian and global reactions were instantaneous. A massive demoralization campaign emerged and the ecological profile of the government was seriously questioned. Correa was labeled traitor, neoliberal, enemy of nature etcetera (as has been the case also with Morales in Bolivia). Oppositional activists demanded that the government should let the Ecuadorian people decide on the future of Yasuní via a popular referendum. Later on, oppositional actors of CONAIE and environmental groups have delivered a request for a popular consultation 
regarding the destiny of the national park and whether to extract or to leave the oil underground. On October $3^{\text {rd }} 2013$, oil drilling in the YasuníITT was approved in the National Assembly, with 108 votes for and 25 against. This support has been confirmed beyond parliament as well.

Even if most Ecuadorians backed up the Yasuní-ITT Initiative previously, many government supporters agree with the arguments behind the decision to initiate oil drilling in a limited area of Yasuní. The Indigenous population of the Amazon is divided around this issue. Whereas the Amazonian federation CONFENIAE ${ }^{11}$ and its national umbrella organization CONAIE mobilize against the government, other Indigenous groups have manifested support of Correa. For instance, on September $13^{\text {th }} 2013$, a multitude of Amazonians organized a march in Quito, spearheaded by 30 Indigenous mayors of the Amazon manifested their approval of the oil drilling in order to improve social conditions. They also approached the Constitutional Court to deliver a request for a popular consultation to approve the exploitation (El Comercio 2013). Just days before the delivery of the final draft of this study, the Yasunited network (Yasunidos) delivered a collection of 727.947 signatures to encourage the organization of a referendum to halt the exploitation of the three oil blocks in the Yasuní (El Universo 2014). ${ }^{12}$

\section{7}

\section{The Rights of Nature as a Straitjacket for Pro- gressive Development Politics?}

Shouldn't we protect the environment? Of course we should! Our Constitution establishes that and we have approved extraordinarily avantgardist laws in this sense. The government is concerned with balancing the necessity of wealth generation to redistribute it. We are also obliged to protect the natural fundament of the planet. But that is a decision and task of OUR state, our legislation, our government and our public policies. The Amazon is ours, of the Bolivians, neither of North Americans, Europeans, nor of companies or NGOs that pretend «teaching us how to protect it». If they wish to protect the environment, they should do it with their forests, floods and hills instead of interfering in how we decide to cherish our natural environment (García Linera 2012: 66).

This declaration by Bolivian vice-President Álvaro García Linera touches the core of the delicate challenge faced by the radical governments and the theoretical framing of the present study, i.e., the tensions between progressive welfare politics, extractivism and the rights of nature and the Indigenous peoples.

In concrete situations of development policies, in Bolivia and Ecuador the rights of nature and ethnically defined peoples have frequently caused complications, as described above, for instance considering the ongoing conflicts of TIPNIS and Yasuní-ITT. The years 2009-2013 have been characterized by processes of subsequent legislation and the crea-
11 Confederación de las Nacionalidades Indígenas de la Amazonia Ecuatoriana.

12 According to the Ecuadorian legal Code of Democracy, a number corresponding to $5 \%$ of the electoral base (i.e., 584000 signatures) would be sufficient to demand before the National Electoral Council (CNE) that the referendum should be held. However, on May 6th 2014, the CNE announced that irregularities had been observed in the gathering of signatures. A number of citizens had signed several times (up to nine times) and some had signed with fictive names, such as Darth Wader (of Star Wars) and Bruce Wayne (of Batman). After the disqualification of these and other irregularities - as decided by the CNEonly 359761 names were approved, which evidently was insufficient. 
tion of new state entities to adapt to the constitutional reform (on decentralization, territorial autonomy, participation, mining, water etc.). Constitutions can thus be viewed as organic documents that change over time and depend on secondary legislation, judicial interpretation and the interplay with State development plans for their performance.

The practical possibilities established in the new constitutions regarding the rights of nature and the Indigenous peoples need to be rooted socially, and this consciousness-raising process concerning ethnic and environmental rights involve learning processes and require time as well as clarity in the judicial texts. Since there are contradictions in the legal texts, the outcome of each conflict that emerges depends on the actors'abilities to achieve support for their particular grievances.

A somewhat contradictory image of the Correa government in Ecuador emerges, regarding the rights of nature and the Indigenous peoples. On the one hand, Ecuador has the most progressive Constitution in the world as for the recognition of proper rights of the environment/Mother Earth, and likewise the rights of the Indigenous peoples. Moreover, the emblematic Yasuni-ITT project -leave the oil underground - is a groundbreaking approach to the climate crisis, resource management, a more solidary attitude towards the rights of nature and the Indigenous peoples, and similarly constitutes a challenge to global capitalism.

On the other hand, the new constitutional rights of nature and the Indigenous peoples have evolved into a kind of straitjacket for the national governments and environmental activists claim that these rights in practice frequently are ignored. As argued, the natural resources are needed for social reforms, infrastructure and anti-poverty policies. The extractivist politics of the Correa administration are far more intense than those of previous governments (as is the case also with the Morales administration in Bolivia). In December 2012, Correa pronounced the following regarding human-nature relations and priorities in State development policies:

Ecuador is not the same as six years ago, the environmental standards have to be higher and higher, and they are indeed, particularly in Ecuador where we have the greenest Constitution of the planet, the first and possibly unique one in recognizing the rights of Mother Earth [...] But, always [human] life first; and there is no mutually excluding relationship here, as some people pretend. On the contrary, I insist, our non-renewable natural resources will not only be used to cherish this biodiversity, our nature, but we must not forget that even if Pachamama has many important things (locus of reproduction and generation of life), human beings remain the most important (Correa Delgado 2012: 4-5).

The justification on behalf of the national governments of both Rafael Correa and Evo Morales clearly fall within the categorical framework of environmental pragmatism. In the quotation above the supremacy of human values vis-à-vis nature is openly expressed, as also the justification of legitimacy amidst progressive neo-extractivism, namely that the revenues derived from resource extractivism are needed for the common good, i.e., to improve infrastructure, health, education and poverty re- 
duction. As previously stated, during the administration of Morales and Correa in Bolivia and Ecuador respectively, huge investments have been made in social programs, health, education, infrastructure, and so on, and the statistics show improvements in reduction of poverty and socioeconomic equality in both countries.

Pablo Dávalos ${ }^{13}$ highlights that social spending, mainly in education and health, undoubtedly has increased in the Ecuador of Correa-PAIS. As an example, the relative share of the GNP invested in social welfare has increased from $6,1 \%$ in 2005 to $14,7 \%$ in 2011. However, what Dávalos aims to criticize is the neo-extractive argument that the incomes of the resource exploitation should be used for social welfare politics. If the expansion of state incomes from the oil industry is considered, in 2005 the State oil revenues were slightly more than $25 \%$ of the petroleum incomes of 2011. Accordingly, as a proportion of the extractive incomes the share dedicated to social welfare shows a relative decrease, even if the amount of money invested in education and health has increased (Dávalos 2013: 192).

The practical implications of Buen-Vivir/Sumak Kawsay in the political debate could be better comprehended through the comparison of different interpretations and/or visions on behalf of involved actors towards the concept, as argued by economist Antonio Luis Hidalgo-Capitán and political scientist Ana Patricia Cubillo-Guevara (2014: 27-29). Roughly speaking, three categories may be identified: the Indigenous peoples; the post-developmentalism and radical ecologist movement; and finally the socialists. Whereas the Indigenous viewpoint highlights the human being as integrated with nature, the radical ecologists place the rights of nature before those of human beings in this simplified categorization. The socialists, on the other hand, view human needs as superior to the rights of nature, i.e., human beings should benefit from the resources of nature, which in this article would correspond to the standpoint of environmental pragmatism.

However, in practice there is no exact frontier between the three «categories» or viewpoints. Also René Ramírez - co-author of the Ecuadorian Development Plan for the Buen Vivir - who according to the above reasoning represents the socialist approach, has expressed the ambition to provide alternatives to development through the Good Way of Living. ${ }^{14}$ By the same token, neither the leftist ecologist opposition, nor the Indigenous organizations in Bolivia and Ecuador are that extreme, i.e., to continuously place nature before the human being and oppose «development» (radical ecologist vision) or to always view Pachamama as sacred (Indigenous view). ${ }^{15}$

To further problematize the analytical scenarios and the fuzzy boundary between ecocentrism and environmental pragmatism, it is important to highlight that most Ecuadorian organizations that mobilize against the extractive policies of the Correa government are not demanding the immediate suspension of all oil and mining exploitation.
13 Dávalos is today one of the toughest Leftist critics of the Correa-PAIS government. Interestingly, before Correa was elected President, while being Minister of Economy in an interim government, Dávalos served as his vice-minister. This is only one example of highranking leftist and environmentalist intellectuals that previously worked closely together with President Correa but later left for the oppositional Left. Other examples are Amazonian Kichwa leader Monica Chuji and previously mentioned and quoted Alberto Acosta.

14 For instance, in an interview published in 2011, he declared that: «We believe that the world does not need development alternatives but alternatives to development. It is necessary to create a completely different world" (Ramírez Gallegos interviewed in Navarette 2011).

15 Indigenous peoples have of course always taken advantages of the natural wealth provided by Mother Earth, albeit with respect and asking her (Pachamama) for permission before initiating any work or action affecting the state of nature and the environment. 
Rather, they suggest that the State economic policies should be oriented towards bio-knowledge and tourism and demand that traditional artisan mining should not be replaced by a new larger-scale model of extractivism that according to them would clash with the environmental objectives of the Buen Vivir Development Plan (Lalander and Ospina Peralta 2012: 30).

Returning to what Correa declared regarding «human life first», before the rights of nature/Pachamama, lawyer Mary Elizabeth Whittemore (2011) provides a rather skeptical consideration regarding the impacts of the constitutional recognition of nature. Essentially, she argues that the articles on the rights of nature are vaguely formulated in the constitution and that they in practice risk losing supremacy and remain sub-ordinated to human values and needs.

It is important to reflect upon the inbuilt ambiguities and challenges within the Sumak Kawsay and Living Well concepts. To Live Well is equally associated to the politics of poverty reduction and the provision of basic rights and a minimum living standard to the population (education, health, infrastructure, electricity, water, communication, mobile phones, access to Internet, etc.). So, one may question whether Sumak Kawsay without development at all would be possible, departing in the current Bolivian and Ecuadorian social contexts?

In the preceding section, President Correa spoke about false dilemmas regarding nature-extractivism relations, and in other discourses he discusses the idea of a «responsible extractivism», "responsible mining» or «environmental-friendly extractivism». Correa justifies his environmentalist position and defends himself against the accusations of the Indigenous and ecologist opposition regarding the alleged extractivist profile of his government:

We are environmentalists; and I am capable of saying that since I worked as a teacher, among others in environmental economics. We are environmentalists, but not in the same sense as those naïve ones that consider human beings to be slightly less than an obstruction for nature. For us, and for the Revolution, the human being is not the only important thing, but still more important than Pachamama. We cannot be beggars sitting on a sack of gold. Those extremist groups do not even admit having information, not even that it is explored to eventually make informed decisions. This indicates ignorance: not even wishing to know, to decline, fear information and fear knowledge (Correa Delgado 2012: 17-18). ${ }^{16}$

16 For critical reflections (radical ecologist and/or postdevelopmentalist positions) regarding the tensions between extractivism and the rights of nature and the Indigenous peoples in today's Ecuador, see Acosta et al., 2013.
Rounding off, on February $17^{\text {th }} 2013$, Rafael Correa was re-elected President and his political movement PAIS achieved a strengthened position in the National Assembly. The Indigenous and ecologist opposition backed up Alberto Acosta as a presidential candidate, although he merely achieved around $3 \%$ of the votes. As for the probable oil drilling in the Yasuní, it is expected to initiate by the end of 2015, that is, if not halted by a public referendum. 
In Bolivia, considering the forthcoming national elections of October 2014 , it will be necessary to take into consideration that the relative positioning of the central actors - and their respective strategies - may be altered depending on the outcome of these elections. In practice, political activists are already in pre-campaign and President Evo Morales aims at re-election. As for the expansion of extractive politics, in February 2014 Morales inaugurated the first large-scale Chinese-made pilot plant for the production of lithium-ion batteries for cellphones and electric vehicles. He highlighted the generous character of Mother Earth:

Evidently, Bolivia has the largest lithium reserves of the entire world, that's our Mother Earth. And this richness is concentrated in the Department of Potosí, a small part of the Department of Oruro, the Salar de Coipasa. You could not imagine how Mother Nature provides us natural resources (Morales Ayma 2014 b).

\section{8 \\ Conclusions}

The Andean experiences with the constitutional recognition of the rights of nature examined in this essay highlight new interpretations of the notion of human and economic development in harmony with the environment. Bolivia and - particularly - Ecuador have undeniably challenged the world giving nature a proper legal voice, at least indirectly, proposing a new model of state-nature-society relations around the Indigenous concept of Sumak Kawsay/Living Well. Nonetheless, as has been analytically depicted in this article, the constitutional contradictions regarding the rights of nature and the Indigenous peoples versus the rights of the State to exploit and commercialize natural resources as long as the incomes are used for the common good have been in the epicenter of recent social clashes between environmental and ethnic social movements and the Bolivian and Ecuadorian governments. The recent TIPNIS and Yasuní conflicts are clear examples of this. Is the Sumak Kawsay model at all possible without «development» (economic growth) or is development a pre-condition in the road towards the Good Way of Living with social welfare for all in these countries still plagued by poverty?

Regarding the actors' discourses on these themes, a differentiation and analytical categorization between ecocentric and environmentally pragmatic positions respectively have been used, particularly leaning on examples from the Ecuadorian context. All involved actors in the conflicts portrayed above claim being defenders of the rights of nature, although the pragmatists present a more realist and relative approach towards these issues, generally placing human values as superior to those of nature. The more ecocentric actors, on the other hand, in the most extreme or utopic varieties instead consider nature as sacred, and more important than economic goals and welfare policies derived from economic growth. However, a degree of pragmatism can be observed 
also within the ecologist opposition. Evidently, many oppositional ecologists do not request immediate abolition of extractivism or some level of economic development, although they propose alternative routes to reach a more ecologic society.

Of course, the question of the centrality of the constitution and the inherent constitutional contradictions amidst social conflicts could be further problematized. In other countries without progressive constitutions in the field of the rights of nature one may find similar conflicts centered in the struggle of ethnically defined rights and the protection of nature. Certainly the constitutions and secondary legislation are important pieces of the puzzle and a fundamental benchmark, but just how important remains to be seen. Constitutional protection of the environment is an important step towards a greener society, although the interplay between legal structures, state policies and societal reactions similarly forms part of the equation. Furthermore, if the constitution is vaguely articulated and/or includes contradictions, for instance as reflected in the present study, then the practical challenges will be more uncertain. Based on the material presented in this study, the more pragmatic anthropocentric view on nature tends to characterize the governments of Correa and Morales, even if their ambitions to safeguard the environment through constitutional reform, secondary legislation, state policies and improved technology and socio-cultural awareness on these issues should not be downplayed.

More research on this complex theme is warranted, also in the more philosophical dimensions and the problematization of what the concepts of common good, welfare, progress, development, coexistence and so forth really mean, from different angles. By the same token, the global image of Ecuador and Bolivia as the emblematic alternatives to the climate crisis and the world capitalist system is at stake precisely due to the pragmatic approach of the State in situations of conflicts regarding the constitutional rights of nature and the Indigenous peoples.

\section{Acknowledgment}

This study is a research advancement of the project Rights of $\mathrm{Na}$ ture-Nature of Rights. Neo-Constitutionalism and Ethno-Ecologist Resistance in Bolivia and Ecuador, supported by FORMAS (Swedish Research Council for Environment, Agricultural Sciences and Spatial Planning) for the period 2013-2016. The author would like to thank two anonymous peer-reviewers of the journal for constructive comments on a previous draft of the article, and likewise sociologist Almut Schilling-Vacaflor and informants and colleagues in Bolivia and Ecuador during fieldwork in Bolivia and Ecuador between March and April, 2013 and January and March, 2014 


\section{Bibliography ${ }^{17}$}

ACOSTA A (2009). La maldición de la abundancia. Quito, Abya-Yala

ACOSTA A (2012). Buen vivir y Sumak kawsay. Una oportunidad para imaginar otros mundos. Quito, Abya-Yala

ACOSTA A, ET AL. (2013). El correísmo al desnudo, Quito, Montecristi Vive

ALBÓ X (2013). Réquiem por el Parque Nacional Yasuní. Resource document. ALAl, América Latina en Movimiento; http://www.alainet.org/active/66580

ALBRO R (2010). Confounding Cultural Citizenship and Constitutional Reform in Bolivia. Latin American Perspectives 37(3)

ARSEL M, ÁVILA Á N (2012). "Stating» Nature's Role in Ecuadorian Development. Civil Society and the Yasuní-ITT Initiative. Journal of Developing Societies 28(2)

BEBBINGTON A, HUMPHREYS B D (2010). An Andean Avatar: Post-neoliberal and neoliberal strategies for promoting extractive industries. BWPI Working Paper 117, University of Manchester

CEPAL (2013). Panorama social de América Latina 2013. Comisión Económica para América Latina y el Caribe/CEPAL. Available at: http://www.eclac.cl/publicaciones/ xml/9/51769/PanoramaSocial2013.pdf

CHUJí GUALINGA M (2014). Sumak Kawsay versus desarrollo. In: Hidalgo Capitán A L, Guillén García A, Deleg Guazha N (eds.). Sumak Kawsay Yuyay. Antología del pensamiento indigenista ecuatoriano sobre Sumak Kawsay. Centro de Investigación en Migraciones/CIM, Universidad de Huelva y Programa Interdisciplinario de Población y Desarrollo Local Sustentable/PYDLOS, Universidad de Cuenca.

CORREA DELGADO R (2012). Lanzamiento de la decimoprimera ronda petrolera. Presidential discourse, Quito, 28 dic. 2012; http://www.presidencia.gob.ec/wp-content/uploads/ downloads/2013/02/2012-11-28-DECIMOPRIMERA-RONDA-PETROLERA.pdf

CORREA DELGADO R (2013). Cadena Nacional sobre Iniciativa Yasuní ITT. Televised speech; https://www.youtube.com/watch?v=IFc1topfPqM

DÁVALOS P (2013). No podemos ser mendigos sentados en un saco de oro. Las falacias del discurso extractivista. In: Acosta A et al. El correísmo al desnudo. Quito, Montecristi Vive

ECKERSLEY R (2002). Environmental Pragmatism, Ecocentrism and Deliberative Democracy: Between Problem-solving and Fundamental Critique (Manuscript). In: Minteer B A, Pepperman Taylor B (eds.), Democracy and the Claims of Nature: Critical Perspectives for a New Century. Maryland, Rowman et Littlefield Publishers

EL COMERCIO (Ecuador) (2013). Grupos amazónicos apoyan la explotación, 14 September, 2013; http://www.elcomercio.com/politica/amazonicos-apoyan-explotacionYasuni-Ecuador_0_992900789.html

EL TELÉGRAFO (2014). Yasunidos no alcanza firmas para consulta popular sobre Yasuní. 7 May 2014. Available at: http://www.telegrafo.com.ec/politica/item/yasunidos-noalcanza-firmas-para-consulta-popular-sobre-yasuni.html

EL UNIVERSO (2014). Con 727947 firmas, colectivo YASunidos espera concretar su consulta popular. 11 April 2014. Available at: http://www.eluniverso.com/noticias/2014/ 04/11/nota/2675491/727947-firmas-colectivo-espera-concretar-su-consulta

ESTADO PLURINACIONAL DE BOLIVIA (2009). Constitución política del Estado. La Paz, Estado Plurinacional de Bolivia

ESTADO PLURINACIONAL DE BOLIVIA (2012). Ley marco de la madre tierra y desarrollo integral para vivir bien. La Paz, Asamblea Legislativa del Estado Plurinacional de Bolivia

FUNDACIÓN TIERRA (2012). Marcha indígena por el TIPNIS. La lucha en defensa de los territorios. La Paz, Comunicaciones El País, S.A.

GARCÍA LINERA Á (2012). Geopolítica de la Amazonía. Poder hacendal-patrimonial y acumulación capitalista. La Paz, Vicepresidencia del Estado Plurinacional, Presidencia de la Asamblea Legislativa Plurinacional

GARCÍA LINERA Á (2013). Los desafíos del proceso de cambio en Bolivia. Conferencia en el Centro Cultural de Cooperación Floreal Gorini, Buenos Aires, 27/06/13. Available at: http://www.centrocultural.coop/videos/la-patria-grande-alvaro-garcia-linera--1-.html

17 All internet sources revised in April 2014. 
GUDYNAS E (2009a). El mandato ecológico. Derechos de la Naturaleza y políticas ambientales en la nueva Constitución. Quito, Abya Yala

GUDYNAS E (2009b). Diez tesis urgentes sobre el nuevo extractivismo. Contextos y demandas bajo el progresismo sudamericano actual. In: VV AA (ed.), Extractivismo, política y sociedad, ed. VV AA. Quito, CAAP (Centro Andino de Acción Popular) y CLAES (Centro Latino Americano de Ecología Social)

GUDYNAS E (2011). Buen vivir: Today's tomorrow. Development 54(4)

HIDALGO-CAPITÁN A L, CUBILLO-GUEVARA A P (2014). Seis debates abiertos sobre el Sumak Kawsay. Íconos. Revista de Ciencias Sociales48. Quito, FLACSO

HIDALGO CAPITÁN A L, GUILLÉN GARCÍA A, DELEG GUAZHA N (2014) (eds.). Sumak Kawsay Yuyay. Antología del pensamiento indigenista ecuatoriano sobre Sumak Kawsay. Centro de Investigación en Migraciones/CIM, Universidad de Huelva y Programa Interdisciplinario de Población y Desarrollo Local Sustentable/PYDLOS, Universidad de Cuenca. Available at: http://www.uhu.es/cim/documents/agenda/libro_sumak.pdf

KENNEMORE A, WEEKS G (2011). Twenty-First Century Socialism? The Elusive Search for a Post-Neoliberal Development Model in Bolivia and Ecuador. Bulletin of Latin American Research 30(3)

LALANDER R, OSPINA PERALTA P (2012). Movimiento indígena y revolución ciudadana en Ecuador. Cuestiones políticas 28(48). Universidad del Zulia, Maracaibo

LATORRE TOMÁS S (2012). El movimiento ecologista popular anti-minero en el Ecuador. Ecuador Debate 87, CAAP (Centro Andino de Acción Popular), Quito

MCNEISH J A (2013). Extraction, Protest and Indigeneity in Bolivia: The TIPNIS Effect. Latin American and Caribbean Ethnic Studies 8(2)

MORALES AYMA E (2011). The Earth does not belong to us, we belong to the Earth. La Paz, Ministry of Foreign Affairs, Plurinational State of Bolivia

MORALES AYMA E (2014a). Presidente Evo Morales. Informe de la gestión 2013 al pueblo boliviano, 22 January 2014, La Paz, Asamblea Legislativa Plurinacional.

MORALES AYMA E (2014b). Inauguración de la Planta Piloto de Baterías de lón Litio. Presidential Discourse, Palca, Potosí, 17 February 2014. Available at: http://www. comunicacion.gob.bo/sites/default/files/media/discursos/Discurso\%20del\%20 presidente $\% 20$ Evo\%20Morales \%20en \%20la\%20Inauguraci\%C3\%B3n\%20 de \%20la \%20Planta\%20Piloto\%20de\%20Bater\%C3\%ADas\%20de\% 20 I\%C3\%B3n\%20Litio\%2017.02.2014.pdf

NAVARETTE R (2011). Seeds of «Good Living» in Ecuador? New Left Project. Available at: http://www.newleftproject.org/index.php/site/article_comments/good_living_in_rafael_correas_ecuador

PÁGINA SIETE (2014). El vicepresidente descarta carretera por el TIPNIS. 04/01/2014. Available at: http://www.paginasiete.bo/nacional/2014/1/4/vicepresidente-descarta-carretera-tipnis-10441.html

PARKER K A (1996). Pragmatism and Environmental Thought. In: Light A \& Katz E (eds.). Environmental Pragmatism. London and y New York, Routledge

PRADA ALCOREZA R (2014). Despojamiento y desposesión extractivista imperial. Las condiciones jurídicas y políticas constitucionales sobre recursos naturales y minería. Rebelión, 14-04-2014. Available at: http://www.rebelion.org/noticia.php?id=183337 \&titular=despojamiento-y-desposesi\%F3n-extractivista-imperial

RAMÍREZ GALLEGOS R (2012). Izquierda y «buen capitalismo». Un aporte crítico desde América Latina. Nueva Sociedad 237:32-48

REPÚBLICA DEL ECUADOR (2008). Constitución política del Ecuador (2008). ${ }^{18}$ Montecristi, Asamblea Nacional Constituyente

18 An English translation of the Ecuadorian Constitution can be found at the Political Database of the Americas: http://pdba. georgetown.edu/Constitutions/ Ecuador/english08.html.
ENPLADES (2009). National Plan for Good Living 2009-2013: Building a Plurinational and Intercultural State (summarized version). Quito, Republic of Ecuador, National Planning and Development Secretary/SENPLADES

SENPLADES/SECRETARÍA NACIONAL DE PLANIFICACIÓN Y DESARROLLO (2013). Plan nacional para el buen vivir 2013-2017. Quito, SENPLADES. www.buenvivir.gob.ec

UNFCCC (United Nations Framework Convention on Climate Change) (2011). Ad Hoc Working Group on Long-term Cooperative Action under the Convention. UNFCCC. Available at: http://unfccc.int/resource/docs/2011/awglca14/eng/misc02.pdf 
WANDERLEY F (2011). The Economy of the Extractive Industries. Poverty and Social Equality. Harvard Review of Latin America. Fall 2011. Available at: http://revista.drclas.harvard.edu/publications/revistaonline/fall-2011/economy-extractive-industries

WHITTEMORE M E (2011). The Problem of Enforcing Nature's Rights under Ecuador's Constitution: Why the 2008 Environmental Amendments have No Bite. Pacific Rim Law and Policy Journal 20(3) 